\title{
ODREDNICE PRIMJENE STRATEGIJA ZA PROMJENU TJELESNOG IZGLEDA U ADOLESCENCIJI
}

\author{
Inja Erceg \\ Sveučilište u Zagrebu, Filozofski fakultet, Odsjek za psihologiju \\ Ivana Lučića 3, 10000 Zagreb \\ inerceg@ffzg.hr \\ Gordana Kuterovac Jagodić \\ Sveučilište u Zagrebu, Filozofski fakultet, Odsjek za psihologiju \\ Ivana Lučića 3, 10000 Zagreb \\ gkuterovac@ffzg.hr
}

\begin{abstract}
Sažetak
Strategije za promjenu tjelesnog izgleda uključuju različite načine mijenjanja i utjecanja na oblik, veličinu i/ili težinu tijela, kao i na njegovu mišićavost. Jedan od čimbenika primjene ovih strategija je nezadovoljstvo tijelom kao subjektivna negativna procjena vlastitog tjelesnog izgleda. Međutim, uloga važnosti slike tijela u njihovoj primjeni je do sada još uvijek manje istražena. Stoga je cilj ovog istraživanja bio ispitati doprinos roda, indeksa tjelesne mase, nezadovoljstva tijelom i važnosti slike tijela u objašnjavanju čestine primjene strategija za promjenu tjelesnog izgleda (strategija mršavljenja, dobivanja na tjelesnoj težini, učvršćivanja mišića i povećanja mišića) te moderatorski utjecaj važnosti slike tijela na odnos između nezadovoljstva tijelom i čestine primjene navedenih strategija za promjenu tjelesnog izgleda. 1056 učenika i učenica osnovnih i srednjih škola prosječne dobi 15-14 godina ispunilo je prevedenu i prilagođenu verziju Inventara slike tijela i promjene tjelesnog izgleda. Rezultati istraživanja pokazuju kako ženski rod, viši indeks tjelesne mase, više nezadovoljstvo tijelom i veća važnost slike tijela doprinose objašnjavanju čestine primjene strategija mršavljenja, dok muški rod, niži indeks tjelesne mase i veća važnost slike tijela doprinose objašnjavanju čestine primjene strategija dobivanja na tjelesnoj težini. Kao značajni prediktori čestine primjene strategija učvršćivanja i povećanja mišića pokazali su se muški rod i veća važnost slike tijela. Nalaz kako je važnost slike tijela prediktor svih ispitanih strategija za promjenu tjelesnog izgleda upućuje na njenu bitnu ulogu u njihovoj primjeni, zbog čega bi na nju bilo potrebno usmjeriti više pažnje u istraživanjima iz ovog područja.
\end{abstract}

Ključne riječi: nezadovoljstvo tijelom, važnost slike tijela, strategije za promjenu tjelesnog izgleda, indeks tjelesne mase, adolescencija 


\section{UVOD}

\section{Strategije za promjenu tjelesnog izgleda}

Strategije za promjenu tjelesnog izgleda, kao načini mijenjanja i utjecanja na oblik, mišićavost, veličinu i/ili težinu tijela, zauzimaju važno mjesto u životima djevojaka i mladića u adolescenciji, razdoblju velikih i značajnih promjena na mnogim razvojnim područjima, a posebice onom tjelesnom. Neke od najčešće primjenjivanih strategija za promjenu tjelesnog izgleda koje će biti prikazane u nastavku jesu: strategije mršavljenja, strategije dobivanja na tjelesnoj težini te strategije povećanja mišićavosti - povećanja mišićnog tonusa i povećanja mišićne mase.

Dok se neke strategije za promjenu tjelesnog izgleda smatraju zdravima, poput odabira zdravih namirnica u prehrani, izbjegavanja masti i rafinirane hrane te umjerene tjelesne aktivnosti, neke su strategije nezdrave te mogu imati štetne posljedice kako na tjelesno, tako i na mentalno zdravlje. U takve se strategije ubrajaju stroge restriktivne dijete (ekstremno izgladnjivanje), preskakanje obroka, uzimanje tableta za mršavljenje, pretjerana tjelesna aktivnost, kompenzacijske strategije nakon unosa hrane - uzimanje laksativa i/ili diuretika te povraćanje, kao i uzimanje steroida radi izgradnje mišićne mase (McCabe i Ricciardelli, 2004). Dijeta je, kao način kontrole tjelesne težine, vrlo rašireno i učestalo ponašanje, a prema nekim autorima, do te mjere da se smatra normativnim, posebice među djevojkama (Livazović i Mudrinić, 2017; McHale, Corneal, Crouter i Birch, 2001; Smink, van Hoeken i Hoek, 2012). Provođenje strogih dijeta predstavlja problematično ponašanje jer može dovesti do fluktuacija u tjelesnoj težini te prejedanja štetnih za zdravlje. Stroge dijete mogu biti povezane is razvojem poremećaja hranjenja, kao i s drugim zdravstvenim problemima poput depresivnosti, anksioznosti, metaboličkih i endokrinoloških poremećaja (Crow, Eisenberg, Story i Neumark-Sztainer, 2006; Gutin, 2011; Rawana, 2013).

Osim strategija mršavljenja, i strategije povećanja mišićavosti mogu imati štetne i ozbiljne zdravstvene posljedice, posebice ako uključuju vježbanje do tjelesnog iscrpljivanja i uzimanje anaboličkih steroida (Cafri i sur., 2005; McCabe i Ricciardelli; 2001; McCabe i Ricciardelli, 2003a). Uzimanje steroida se povezuje s vrlo ozbiljnim zdravstvenim problemima poput hipertenzije, ateroskleroze, infarkta miokarda, moždanog udara, bolesti jetre, agresivnosti, promjena raspoloženja, depresije pa čak i maničnih i psihotičnih epizoda (Angell i sur., 2012; Cafri i sur., 2005; Harris, Dunn i Alwyn, 2016; Pope i sur., 2013).

\section{Čimbenici primjene strategija za promjenu tjelesnog izgleda}

Na sklonost primjeni strategija za promjenu tjelesnog izgleda ne utječe samo rod adolescenta već i cijeli niz drugih čimbenika, od kojih će ovdje biti prikazani 
neki od češće ispitivanih varijabli poput indeksa tjelesne mase i nezadovoljstva tijelom, kao i manje istražen koncept važnosti slike tijela.

Primjena strategija za promjenu tjelesnog izgleda uvelike ovisi o sociokulturalnim idealima tjelesnog izgleda koji su uvjetovani rodom. U skladu s društveno uvjetovanim idealom mršavog ženskog tijela, djevojke su sklonije primjeni strategija mršavljenja (provođenju restriktivnih dijeta, odstupajućim navikama hranjenja, primjeni tableta i drugih sredstava za mršavljenje te kompenzacijskih strategija nakon unosa hrane) koje su među njima ujedno i najučestalije (Karazsia, Murnen i Tylka, 2017; Levine i Smolak, 2002; Livazović i Mudrinić, 2017; Munjas Samarin, 2011; Pokrajac-Bulian, Mohorić i Đurović, 2007). S druge strane, u skladu s idealom mišićavog muškog tijela, mladići izražavaju želju za izgradnjom svoga tijela i njegove mišićavosti te su, više nego djevojke, skloni primjeni strategija dobivanja na tjelesnoj težini i povećanja mišićavosti, uključujući i uzimanje proteinskih napitaka te, u manjem broju slučajeva, i steroida (Karazsia i sur., 2017; Kukić, 2013; McCabe i Ricciardelli, 2001; McCabe i Ricciardelli, 2004).

Indeks tjelesne mase (ITM; engl. Body mass index, BMI) objektivna je mjera kojom se može odrediti stupanj uhranjenosti osobe, a izračunava se dijeljenjem tjelesne težine osobe izražene u kilogramima s kvadratom njene tjelesne visine izražene u metrima. Prema ovom indeksu odrasle se osobe mogu podijeliti u nekoliko kategorija: pothranjene (ITM $<18,5)$, normalno teške $(18,6-24,9)$, prekomjerno teške $(25,0-29,9)$ i pretile $(\geq 30,0)$. Pretilost se nadalje dijeli u tri stupnja: pretilost I. stupnja (30,0-34,9), II. stupnja (35,0-39,9) i III. stupnja ( $\geq 40,0)$. Međutim, kod djece se stupanj uhranjenosti određuje prema tablicama centilnih vrijednosti indeksa tjelesne mase djevojčica i dječaka. Indeks tjelesne mase manji od 5. centila za dob i rod upućuje na pothranjenost, između 5. i 85. centila na normalnu tjelesnu težinu, od 85. do 95. centila na prekomjernu tjelesnu težinu, a jednak ili veći od 95. centila na pretilost (Kukić, 2013).

Rezultati istraživanja provedenih diljem svijeta, uključujući i Hrvatsku, upućuju na pozitivnu povezanost indeksa tjelesne mase i nezadovoljstva tijelom kod adolescentica (Bralić i Kovačić, 2005; Lunner i sur., 2002; Presnell, Bearman i Stice, 2004; Stice i Whitenton, 2002). Ove nalaze podupiru i rezultati istraživanja Pokrajac-Bulian, Stubbs i Ambrosi-Randić (2004), prema kojima su svojim tijelom najzadovoljnije ozbiljno pothranjene djevojke (djevojke vrlo niskog indeksa tjelesne mase) u usporedbi s djevojkama normalne i prekomjerne tjelesne težine. Iako su i prekomjerno teški mladići skloni primjeni strategija mršavljenja (Kukić, 2013; McCabe i Ricciardelli, 2001), to ipak čine u manjoj mjeri nego prekomjerno teške djevojke (Neumark-Sztainer, Story, Hannan, Perry i Irving, 2002). Nadalje, samoprocjene mladića kako ispodprosječne tako i iznadprosječne tjelesne težine, prediktori su primjene anaboličkih steroida (Blashill i Wilhelm, 2014; Jampel, Murray, Griffiths i Blashill, 2016).

Čini se kako je povezanost indeksa tjelesne mase i zadovoljstva tijelom uvjetovana rodom adolescenta. Naime, dok je kod djevojaka taj odnos linearan, kod 
mladića je on zakrivljen. Kod mladića su i prekomjerna tjelesna težina, kao i ona ispodprosječna, prediktori njihova nezadovoljstva tijelom i dugoročnih viših razina depresivnosti (Blashill i Wilhelm, 2014). Razlozi ovih razlika mogu se potražiti u već spomenutim različitim sociokulturalnim pritiscima $\mathrm{k}$ postizanju idealnog tjelesnog izgleda ovisno o rodu. Dok se djevojkama nameće ideal izrazite mršavosti, idealan izgled muškog tijela podrazumijeva mišićavost, široka ramena, ravan i mišićav trbuh te uzak struk i bokove (Tiggemann, 2011).

Nezadovoljstvo tijelom još je jedan od važnih čimbenika primjene strategija za promjenu tjelesnog izgleda. Nezadovoljstvo tijelom subjektivni je aspekt slike tijela, višedimenzionalnog konstrukta koji odražava percepciju, misli i osjećaje osobe vezane uz vlastito tijelo. Ono se može kretati od blagog nezadovoljstva specifičnim dijelovima tijela (npr. bokovima, bedrima, stražnjicom, trbuhom...) pa sve do ekstremnog omalovažavanja vlastitog izgleda koji se uspoređuje s idealnim (Grogan, 2017). U srži nezadovoljstva tijelom je raskorak između percipiranog i unutarnjeg ili društveno uvjetovanog idealnog tjelesnog izgleda (Gardner, Friedman, Stark i Jackson, 1999). Što je raskorak veći, veće je i nezadovoljstvo tijelom. Iako je najveći interes istraživača za nezadovoljstvo tijelom vezan upravo uz njegovu ulogu u nastanku poremećaja hranjenja, ono se pojavljuje kod značajnog dijela nekliničke populacije te je zbog svoje učestalosti u zapadnim kulturama, posebice među djevojkama, postalo gotovo normativno (Gondoli, Corning, Salafia, Bucchianeri i Fitzsimmons, 2011). Prema rezultatima meta-analize čini se kako je nezadovoljstvo tijelom jedan od najznačajnijih prediktora odstupajućih navika hranjenja (Stice, 2002).

Na nastanak i razvoj nezadovoljstva tijelom utječu mnogobrojni čimbenici koji dolaze iz različitih izvora. $U$ objašnjavanju razvoja i/ili održavanja nezadovoljstva tijelom razlikujemo četiri glavna pristupa (Thompson, 1992): (1) pristup socijalne usporedbe; (2) pristup sociokulturalnog pritiska; (3) razvojni pristup (temeljen na razvojnom statusu) i (4) pristup negativnog verbalnog komentara (zadirkivanje, negativne povratne informacije i komentari o tjelesnom izgledu). Svaki od navedenih pristupa objašnjava ulogu nekih od mnogobrojnih čimbenika koji imaju ulogu u nastanku nezadovoljstva tijelom. Prema pristupu socijalne usporedbe, veći rizik za razvoj nezadovoljstva tijelom imaju osobe koje svoj izgled često uspoređuju s izgledom drugih osoba, posebice onih vrlo privlačnih, u odnosu na osobe koje to čine rjeđe. Prema sociokulturalnom pristupu sociokulturalni utjecaji, posebice oni koji uključuju tisak (novine, časopisi i sl.) i vizualne medije (televizijske emisije, filmovi, serije, reklame, glazbeni spotovi...), izvor su snažnih poruka o tome koje su tjelesne karakteristike prihvatljive i poželjne, a koje nisu. Istraživanja koja upućuju na povezanost nezadovoljstva tijelom, štetnih strategija za promjenu tjelesnog izgleda, poremećaja hranjenja i poruka o idealnom tjelesnom izgledu i načinima njegova postizanja koje pristižu iz medija, idu u prilog ovom pristupu. Razvojni pristup usmjeren je na razmatranje vremena pubertalnog sazrijevanja (vremena ulaska u pubertet u odnosu na vršnjake u vlastitoj skupini) kao središnjeg čimbenika razvo- 
ja nezadovoljstva tijelom. Prema pristupu negativnog verbalnog komentara rana izloženost zadirkivanju u formi negativnih primjedbi vezanih uz tjelesni izgled ili težinu povezana je s nezadovoljstvom tijelom, poremećajima hranjenja i narušenim općim psihološkim funkcioniranjem (Cattarin i Thompson, 1994). Kod djevojaka je učestalost zadirkivanja značajno pozitivno povezana s obezvrjeđivanjem vlastitog tijela i precjenjivanjem njegova oblika (Rosen, 1990). Navedeni nalazi doveli su do nastanka hipoteze o negativnom verbalnom komentaru kao bitnom čimbeniku razvoja nezadovoljstva tijelom, poremećaja hranjenja i niskog samopoštovanja.

Raskorak između percipiranog i idealnog tjelesnog izgleda u adolescenciji postaje sve izraženiji, što ovo razdoblje čini posebno osjetljivim za razvoj nezadovoljstva tijelom. S obzirom na to da adolescenti ulaskom u ovo razvojno razdoblje postaju svjesniji sebe, promjene tijela (koje su često drastične) dobivaju značajnu ulogu i prioritet u njihovim životima, odnosno tjelesni izgled postaje jedna od njihovih glavnih prokupacija (Ambrosi-Randić, 2004; Davison i McCabe, 2006; Levine i Smolak, 2002). Tijekom adolescencije nezadovoljstvo tijelom, zabrinutost za tijelo i pokušaji provođenja dijeta imaju važnu ulogu kao rizični čimbenici razvoja niskog samopoštovanja, depresije i poremećaja hranjenja, zbog čega upravo adolescenti predstavljaju najrizičniju skupinu (Ferreiro, Seoane i Senra, 2014; Smink i sur., 2012; Stice i Bearman, 2001; Voelker, Reel i Greenleaf, 2015; Wertheim, Koerner i Paxton, 2001).

Iako je velik broj istraživanja posvećen ulozi nezadovoljstva tijelom kao čimbenika primjene ekstremnih strategija za promjenu tjelesnog izgleda i razvoja poremećaja hranjenja, manji je broj istraživanja uloge važnosti koju osoba pridaje svom tjelesnom izgledu. Međutim, čini se kako je upravo važnost slike tijela, kao i nezadovoljstvo tijelom, značajan čimbenik u razumijevanju sklonosti primjeni određenih strategija za promjenu tjelesnog izgleda, kao i odstupajućih navika hranjenja pa i poremećaja hranjenja (O’Connor, 2014; Rieder i Ruderman, 2001). McCabe i Ricciardelli (2006) navode kako se uz nezadovoljstvo tijelom i važnost slike tijela pokazala snažnim prediktorom ekstremnih ponašanja koja za cilj imaju promjenu tjelesnog izgleda kod adolescenata oba roda.

Sama informacija o tome da osoba želi imati drugačiju veličinu i/ili oblik tijela od sadašnjeg, moguće da nije sama po sebi presudna za nezadovoljstvo tijelom. Značajnu ulogu pritom ima važnost koju osoba pridaje svom tjelesnom izgledu (Cash, 2012; Loth, MacLehose, Bucchianeri, Crow i Neumark-Sztainer, 2014; Ricciardelli i McCabe, 2001). Na taj način važnost vlastitog tjelesnog izgleda može utjecati na (ne)zadovoljstvo tijelom, kao i na druga područja života. Ako osoba ne pridaje veliku važnost tome kako izgleda, manje je vjerojatno da će njezin tjelesni izgled utjecati na njezin osjećaj vlastite vrijednosti, čak i u slučaju da njime nije zadovoljna (Ricciardelli i McCabe, 2001). U tom slučaju, ako je osoba nezadovoljna tijelom, ali vlastiti tjelesni izgled smatra nevažnim, vjerojatnije je kako neće primjenjivati strategije za njegovu promjenu (McCabe i Ricciardelli, 2003a; Rieder i Ruderman, 2001). Giovannelli, Cash, Henson i Engle (2008) pronalaze da mjere 
zadovoljstva tijelom i slike tijela imaju veću konstruktnu valjanost kada u obzir uzimaju i važnost koju osoba pridaje svom tjelesnom izgledu. Cash (2002) i drugi autori (Melnyk, Cash i Janda, 2004; Cash, Melnyk i Hrabosky, 2004; Cash, Phillips, Santos i Hrabosky, 2004; Jakatdar, Cash, i Engle, 2006; Rudiger, Cash, Roehrig i Thompson, 2007; sve prema Giovannelli i sur., 2008) pronalaze da je taj aspekt slike tijela značajniji od samog konstrukta zadovoljstva tijelom u predviđanju raznih aspekata psihosocijalnog funkcioniranja. Nadalje, Muris, Meesters, van de Blom i Mayer (2005) te McCabe i Ricciardelli (2006) navode kako kod mladića tijekom adolescencije na sklonost primjeni strategija za promjenu tjelesnog izgleda snažniji utjecaj ima važnost koju pridaju svom tjelesnom izgledu nego samo nezadovoljstvo njime. No ponešto drugačiju situaciju nalaze kod adolescentica. Naime, djevojke koje veliku važnost pridaju svom tjelesnom izgledu, ali su i njime nezadovoljne, u riziku su za primjenu ekstremnih strategija za promjenu tjelesnog izgleda.

S obzirom na još uvijek razmjerno manje istraženo područje odrednica primjene strategija za promjenu tjelesnog izgleda kod adolescenata oba roda u kontekstu uloge slike tijela, a posebice uloge njene važnosti u njihovoj primjeni, cilj ovog istraživanja bio je ispitati doprinos roda, indeksa tjelesne mase, nezadovoljstva tijelom i važnosti slike tijela u objašnjavanju čestine primjene nekoliko najčešćih strategija za promjenu tjelesnog izgleda (strategija mršavljenja, dobivanja na tjelesnoj težini, učvršćivanja mišića i povećanja mišića) kod djevojaka i mladića u adolescenciji s potencijalno vrlo ozbiljnim posljedicama na tjelesno i mentalno zdravlje. Uz navedeno, ispitan je i moderatorski utjecaj važnosti slike tijela na odnos između nezadovoljstva tijelom i čestine primjene strategija za promjenu tjelesnog izgleda.

\section{METODA}

\section{Uzorak i postupak}

S obzirom na to da je ovo istraživanje dio većeg projekta ispitivanja čimbenika nezadovoljstva tijelom $u$ adolescenciji transverzalnog nacrta, u njemu je sudjelovalo ukupno 1056 učenica i učenika viših razreda osnovne škole (rana adolescencija) i završnih razreda srednje škole (kasna adolescencija) s područja grada Zagreba i Velike Gorice ( $M=15,14, S D=2,55 ; 54 \%$ djevojaka, $46 \%$ mladića).

Provedbu istraživanja odobrilo je Etičko povjerenstvo za istraživanja s ljudi$m a$ Filozofskog fakulteta Sveučilišta u Zagrebu i Agencija za odgoj i obrazovanje Ministarstva znanosti i obrazovanja Republike Hrvatske. Ispitivanje je provedeno grupno u školi za vrijeme sata razrednika u preko 30 razrednih odjeljenja. Prije primjene upitnika učenicima je objašnjena svrha istraživanja te je naglašeno kako je istraživanje u potpunosti anonimno te da od sudjelovanja u njemu mogu odustati u bilo kojem trenutku bez posljedica. Učenici su zamoljeni za suradnju i iskrenost pri odgovaranju. Ispunjavanje upitnika trajalo je između 15 i 20 minuta. 


\section{Mjerni instrumenti}

Za procjenu nezadovoljstva tijelom, važnosti slike tijela i primjene strategija za promjenu tjelesnog izgleda uz dopuštenje autorica primijenjena je prevedena $\mathrm{i}$ prilagođena verzija Inventara slike tijela i promjene tjelesnog izgleda (Body Image and Body Change Inventory; Ricciardelli i McCabe, 2002). Instrument je preveden metodom dvostrukog prijevoda, a razumijevanje čestica provjereno je u predistraživanju provedenom na 78 učenica i učenika viših razreda osnovne škole dobnog raspona od 10 do 14 godina $(M=12,46, S D=0,538 ; 56 \%$ djevojaka) te na 532 učenice i učenika srednjih škola s područja grada Zagreba i Velike Gorice dobnog raspona od 16 do 19 godina $(M=17,54, S D=0,629 ; 55 \%$ djevojaka) (Erceg Jugović, 2015).

Prilagođeni inventar sastojao se od ukupno 63 čestice raspoređene u šest ljestvica. Ljestvice Zadovoljstvo tijelom i Važnost slike tijela sadrže po 14 čestica te ispituju zadovoljstvo i važnost tjelesne težine, visine, oblika tijela, veličine mišića, čvrstoće mišića te izgleda pojedinih dijelova tijela. Faktorska struktura ljestvica ispitana je analizom glavnih komponenata. Kao kriteriji za ekstrakciju faktora korišteni su Guttman-Kaiserov kriterij (vrijednost karakterističnog korijena veća od 1) te Catellov scree test kao grafički prikaz ekstrahiranih faktora koji omogućuje praćenje trenda opadanja vrijednosti karakterističnih korijena. Ekstrahiran je po jedan faktor kao i u originalnom inventaru.

Ljestvica Strategije mršavljenja sadrži devet čestica kojima se ispituje koliko često osoba primjenjuje određene strategije kako bi smanjila svoju tjelesnu težinu: prehranom, tjelovježbom i korištenjem pripravaka za mršavljenje. Ljestvica Strategije dobivanja na tjelesnoj težini sadrži devet čestica kojima se ispituje koliko često osoba primjenjuje određene strategije kako bi povećala svoju tjelesnu težinu: prehranom, tjelovježbom i korištenjem pripravaka za povećanje tjelesne težine. Ljestvica Strategije učvršćivanja mišića sadrži šest čestica kojima se ispituju navike hranjenja i tjelesna aktivnost s ciljem povećanja mišićnog tonusa, a ljestvica Strategije povećanja mišića devet čestica kojima se ispituju navike hranjenja, tjelesna aktivnost i uzimanje dodataka prehrani s ciljem povećanja mišića. Sudionici su odgovarali na skali Likertova tipa od pet stupnjeva: od $1=$ jako nezadovoljan/a do $5=$ jako zadovoljan/a na ljestvici Zadovoljstvo tijelom; od 1 = uopće nije važno do $5=$ jako važno na ljestvici Važnost slike tijela, a na ljestvicama strategija za promjenu tjelesnog izgleda od $1=$ nikad do $5=$ gotovo uvijek. Primjer čestica za zadovoljstvo tijelom je: „,Koliko si zadovoljan/a svojom težinom? “, za važnost slike tijela: „,Koliko ti je važna čvrstoća tvojih mišića? “, za čestinu primjene strategije mršavljenja: ,Koliko često jedeš manje kako bi smršavio/la? “, za strategiju dobivanja na tjelesnoj težini: „Koliko često jedeš više kako bi dobio/la na težini? “, za strategiju učvršćivanja mišića: „Koliko često vježbaš više kako bi učvrstio/la svoje mišiće?" te za strategiju povećanja veličine mišića: „,Koliko često uzimaš dodatke prehrani (npr. proteinske napitke, tablete, sokove) kako bi povećao/la svoje mišiće?”. 
Rezultati se izračunavaju kao jednostavne linearne kombinacije samoprocjena sudionika na česticama unutar svake od ljestvica. Na svim primijenjenim ljestvicama viši rezultat upućuje veće zadovoljstvo tijelom, na veću važnost slike tijela te na veću učestalost primjene pojedinih strategija za promjenu tjelesnog izgleda. Pouzdanosti tipa unutarnje konzistencije na našem uzorku iznose redom: za ljestvicu Zadovoljstvo tijelom $\alpha=0,90$; za ljestvicu Važnost slike tijela $\alpha=0,86$; za ljestvicu Strategije mršavljenja $\alpha=0,92$; za ljestvicu Strategije dobivanja na tjelesnoj težini $\alpha=0,96$; za ljestvicu Strategije učvršćivanja mišića $\alpha=0,89$ te za ljestvicu Strategije povećanja mišića $\alpha=0,94$.

Također su prikupljeni podaci o rodu, dobi, školi, razredu te trenutnoj tjelesnoj težini i visini sudionika.

\section{REZULTATI}

Prije provedbe analiza u svrhu odgovaranja na istraživačke probleme, učinjeno je nekoliko potrebnih preliminarnih analiza. U Tablici 1 prikazani su deskriptivni podaci mjernih instrumenata dobiveni u ovom istraživanju na uzorku adolescenata i adolescentica. Prikazani su podaci o aritmetičkim sredinama, standardnim devijacijama, teoretskom rasponu rezultata, rasponu dobivenih rezultata, broju čestica unutar svake ljestvice te o Kolmogorov-Smirnovljevu testu normalnosti distribucije. Distribucije rezultata istraživačkih varijabli ne odstupaju značajno od normalne. Podaci o rasponu dobivenih rezultata, aritmetičkim sredinama i standardnim devijacijama prikazani su u svojim relativnim vrijednostima, odnosno vrijednostima za česticu. Prosječni indeks tjelesne mase djevojaka iznosio je $M=20,8(S D=2,81)$, a mladića $M=22,7(S D=2,93)$, što prema tablicama centilnih vrijednosti za dob i rod upućuje na normalnu tjelesnu težinu.

Kako bi se ispitao zaseban doprinos roda, indeksa tjelesne mase i nezadovoljstva tijelom u objašnjavanju čestine primjene pojedinih strategija za promjenu tje-

Tablica 1. Deskriptivna statistika istraživačkih varijabli $(N=1056)$

\begin{tabular}{lrrrrrrr}
\hline Mjerni instrument/ljestvica & $k$ & TR & Min & Max & $M$ & $S D$ & $K-S$ \\
\hline Inventar slike tijela i promjene tjelesnog izgleda & & & & & & & \\
$\quad$ Zadovoljstvo tijelom & 14 & $1-5$ & 1 & 5 & 3,64 & 0,721 & 0,06 \\
Važnost slike tijela & 14 & $1-5$ & 1 & 5 & 3,60 & 0,776 & 0,09 \\
Strategija mršavljenja & 9 & $1-5$ & 1 & 5 & 2,24 & 0,985 & 0,11 \\
Strategija dobivanja na tjelesnoj težini & 9 & $1-5$ & 1 & 5 & 1,79 & 0,973 & 0,21 \\
Strategija učvršćivanja mišića & 6 & $1-5$ & 1 & 5 & 2,85 & 1,090 & 0,06 \\
Strategija povećanja mišića & 9 & $1-5$ & 1 & 5 & 2,22 & 0,993 & 0,11 \\
\hline
\end{tabular}

Legenda: $k=$ broj čestica; $T R=$ teoretski totalni raspon rezultata; $M i n=$ najmanji dobiveni rezultat; $M a x=$ najveći dobiveni rezultat; $M=$ aritmetička sredina; $S D=$ standardna devijacija; $K-S=$ Kolmogorov-Smirnovljeva $z$-vrijednost. 
lesnog izgleda (strategije mršavljenja, dobivanja na tjelesnoj težini, učvršćivanja mišića i povećanja mišića), kao i moderatorski utjecaj važnosti slike tijela na odnos između nezadovoljstva tijelom i čestine primjene pojedinih strategija za promjenu tjelesnog izgleda, provedene su četiri hijerarhijske regresijske analize u pet koraka $\mathrm{s}$ ispitivanjem moderatorskog utjecaja važnosti slike tijela. U prvom je koraku hijerarhijskih regresijskih analiza uvedena varijabla roda kao kontrolna varijabla, u drugom varijabla indeksa tjelesne mase kao biološka varijabla, u trećem i četvrtom koraku uvedene su redom varijable nezadovoljstva tijelom (inverzna vrijednost zadovoljstva tijelom) i važnosti slike tijela kao zasebne komponente slike tijela te $u$ posljednjem koraku interakcija varijable nezadovoljstva tijelom i varijable važnost slike tijela. Također je uvođenjem u prvom koraku hijerarhijskih regresijskih analiza provjerena i prediktivnost dobi za čestinu primjene svake od strategija promjene tjelesnog izgleda, no kako se nije pokazala značajnom te kako je u gotovo nultoj korelaciji s kriterijskim varijablama, odlučili smo je izostaviti iz navedenih analiza.

Korelacije među prediktorskim varijablama korištenima u hijerarhijskim regresijskim analizama predviđanja čestine primjene strategija za promjenu tjelesnog izgleda prikazane su u Tablici 2.

Vidljiva je relativno niska, ali značajna negativna povezanost roda i indeksa tjelesne mase te pozitivna povezanost roda i nezadovoljstva tijelom. Mladići imaju viši indeks tjelesne mase od djevojaka, a djevojke pokazuju veće nezadovoljstvo tijelom od mladića, što je u skladu s očekivanjima. Indeks tjelesne mase je, također očekivano, pozitivno povezan s nezadovoljstvom tijelom. Ostali prediktori ne pokazuju međusobne povezanosti.

Rezultati hijerarhijske regresijske analize za predviđanje čestine primjene strategija mršavljenja prikazani su u Tablici 3.

Rezultati hijerarhijske regresijske analize pokazuju kako je rod značajan prediktor strategija mršavljenja kojim je objašnjeno 3\% varijance kriterija. Djevojke češće nego mladići primjenjuju strategije mršavljenja. Uvođenjem varijable indeksa tjelesne mase $u$ drugom koraku, postotak objašnjene varijance kriterija povećava se za značajnih $12 \%$. Adolescenti i adolescentice višeg indeksa tjelesne mase češće

Tablica 2. Pearsonovi koeficijenti korelacija među prediktorskim varijablama korištenima u hijerarhijskim regresijskim analizama predviđanja čestine primjene strategija za promjenu tjelesnog izgleda $(N=1056)$

\begin{tabular}{llccc}
\hline & & 1 & 2 & 3 \\
\hline 1 & Rod & - & & \\
2 & Indeks tjelesne mase & $-0,19^{* *}$ & - & - \\
3 & Nezadovoljstvo tijelom & $0,20^{* *}$ & $0,29^{* *}$ & 0,01 \\
4 & Važnost slike tijela & $-0,01$ & 0,00 & \\
\hline
\end{tabular}

Legenda: ${ }^{* *} p<0,001$; Rod: 1 - mladići, 2 - djevojke. 
Tablica 3. Rezultati hijerarhijske regresijske analize predviđanja čestine primjene strategija mršavljenja $(N=1056)$

\begin{tabular}{|c|c|c|c|c|c|c|}
\hline & \multirow[b]{2}{*}{ Prediktori } & \multicolumn{5}{|c|}{ Koraci } \\
\hline & & $\begin{array}{l}1 . \\
\beta\end{array}$ & $\begin{array}{l}2 . \\
\beta\end{array}$ & $\begin{array}{l}3 . \\
\beta\end{array}$ & $\begin{array}{l}4 . \\
\beta\end{array}$ & $\begin{array}{l}5 . \\
\beta\end{array}$ \\
\hline 1 & Rod & $0,17 * *$ & $0,24 * *$ & $0,18^{* *}$ & $0,18^{* *}$ & 0,17 ** \\
\hline 2 & Indeks tjelesne mase & & $0,35 * *$ & $0,27 * *$ & $0,27 * *$ & $0,27 * *$ \\
\hline 3 & Nezadovoljstvo tijelom & & & $0,24 * *$ & $0,23 * *$ & $0,23 * *$ \\
\hline 4 & Važnost slike tijela & & & & $0,29 * *$ & $0,31 * *$ \\
\hline 5 & $\begin{array}{l}\text { Nezadovoljstvo tijelom } \\
\times \text { Važnost slike tijela }\end{array}$ & & & & & $0,09 *$ \\
\hline & $\mathrm{R}^{2}$ & 0,03 & 0,15 & 0,19 & 0,28 & 0,28 \\
\hline & Korigirani $\mathrm{R}^{2}$ & 0,03 & 0,14 & 0,19 & 0,27 & 0,28 \\
\hline & $\mathrm{F}$ & $31,92 * *$ & $88,83 * *$ & $83,31 * *$ & $99,47 * *$ & $82,40 * *$ \\
\hline & $\Delta \mathrm{R}^{2}$ & & 0,12 & 0,05 & 0,08 & 0,01 \\
\hline & $\Delta \mathrm{F}$ & & $141,48 * *$ & $61,97 * *$ & $119,69 * *$ & $10,51^{*}$ \\
\hline
\end{tabular}

Legenda: $\beta=$ standardizirani regresijski koeficijent; $\mathrm{R}^{2}=$ koeficijent determinacije; Korigirani $\mathrm{R}^{2}=$ vrijednost koeficijenta determinacije korigirana za broj varijabli u modelu; $F=F$-omjer; $\Delta \mathrm{R}^{2}=$ promjena vrijednosti koeficijenta determinacije; $\Delta \mathrm{F}=$ promjena vrijednosti $\mathrm{F}$-omjera; ${ }^{* *} p<0,001 ;{ }^{*} p<$ 0,005; Rod: 1 - mladići, 2 - djevojke.

primjenjuju strategije mršavljenja. Uvođenjem nezadovoljstva tijelom u trećem koraku, postotak objašnjene varijance povećao se za značajnih 5\%. Adolescenti i adolescentice nezadovoljniji tijelom češće primjenjuju strategije mršavljenja. Kada se u četvrtom koraku uvede varijabla važnosti slike tijela, postotak objašnjene varijance ponovno se značajno povećao za $8 \%$. Adolescenti i adolescentice koji slici tijela pridaju veću važnost, češće primjenjuju strategije mršavljenja. Konačno, uvođenjem interakcijskog efekta nezadovoljstva tijelom i važnosti slike tijela u posljednjem koraku, postotak objašnjene varijance kriterija povećao se za niskih, ali značajnih $1 \%$. Dakle, varijable nezadovoljstva tijelom i važnosti slike tijela zasebno, kao i njihova interakcija, pokazali su se značajnim prediktorima primjene strategija mršavljenja. Varijabla važnosti slike tijela ima moderatorski učinak na odnos između nezadovoljstva tijelom i čestine primjene strategija mršavljenja.

Interakcijski efekt važnosti slike tijela i nezadovoljstva tijelom na mjeru čestine primjene strategija mršavljenja prikazan je na Slici 1 u obliku prosječnih vrijednosti čestine primjene strategija mršavljenja kod sudionika s niskim i visokim nezadovoljstvom tijelom ovisno o važnosti koju pridaju svojoj slici tijela.

Možemo vidjeti kako čestina primjene strategija mršavljenja kod adolescenata i adolescentica nezadovoljnih tijelom znatno raste s povećanjem važnosti koju pridaju svojoj slici tijela, dok se kod adolescenata i adolescentica zadovoljnijih tijelom ona tek blago povećava. 


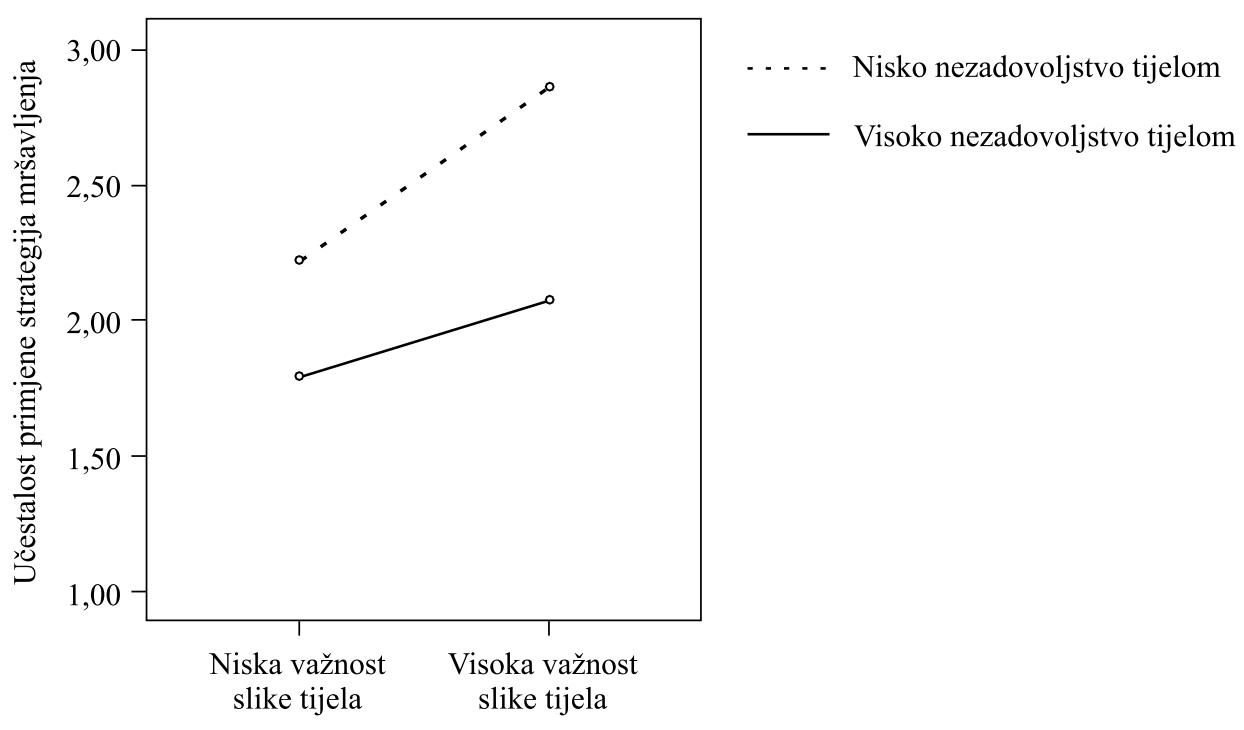

Slika 1. Interakcijski efekt važnosti slike tijela i nezadovoljstva tijelom na mjeru čestine primjene strategija mršavljenja

Model čimbenika čestine primjene strategija mršavljenja dobiven u ovom istraživanju prikazan je na Slici 2.

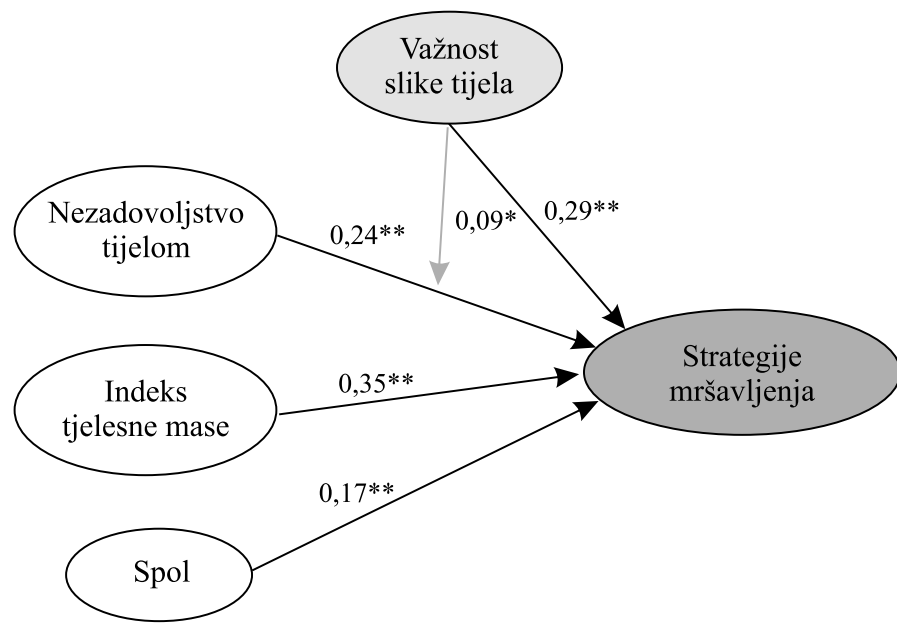

Slika 2. Dobiveni model čimbenika čestine primjene strategija mršavljenja $(N=1056)$ Napomena. Rod: 1 - mladići; 2 - djevojke. Prikazani su standardizirani regresijski koeficijenti $(* * p<0,001 ; * p<0,05)$. 
Tablica 4. Rezultati hijerarhijske regresijske analize predviđanja čestine primjene strategija dobivanja na tjelesnoj težini $(N=1056)$

\begin{tabular}{|c|c|c|c|c|c|c|}
\hline & & & & Koraci & & \\
\hline & Prediktori & $\begin{array}{l}1 . \\
\beta\end{array}$ & $\begin{array}{l}2 . \\
\beta\end{array}$ & $\begin{array}{l}3 . \\
\beta\end{array}$ & $\begin{array}{l}4 . \\
\beta\end{array}$ & $\begin{array}{l}5 . \\
\text { B }\end{array}$ \\
\hline 1 & Rod & $-0,34 * *$ & $-0,38 * *$ & $-0,38^{* *}$ & $-0,37 * *$ & $-0,36^{* *}$ \\
\hline 2 & Indeks tjelesne mase & & $-0,24 * *$ & $-0,23^{* *}$ & $-0,23^{* *}$ & $-0,23^{* *}$ \\
\hline 3 & Nezadovoljstvo tijelom & & & $-0,03$ & $-0,03$ & $-0,02$ \\
\hline 4 & Važnost slike tijela & & & & $0,14 * *$ & $0,12 * *$ \\
\hline 5 & $\begin{array}{l}\text { Nezadovoljstvo tijelom } \\
\times \text { Važnost slike tijela }\end{array}$ & & & & & $-0,09 *$ \\
\hline & $\mathrm{R}^{2}$ & 0,11 & 0,17 & 0,17 & 0,19 & 0,20 \\
\hline & Korigirani $\mathrm{R}^{2}$ & 0,11 & 0,17 & 0,17 & 0,19 & 0,19 \\
\hline & $\mathrm{F}$ & $133,90 * *$ & $106,70 * *$ & $71,36^{* *}$ & $61,44 * *$ & $51,31 * *$ \\
\hline & $\Delta \mathrm{R}^{2}$ & & 0,06 & 0,00 & 0,02 & 0,01 \\
\hline & $\Delta \mathrm{F}$ & & $70,64 * *$ & 0,74 & $26,47 * *$ & $8,92 *$ \\
\hline
\end{tabular}

Legenda: $\beta=$ standardizirani regresijski koeficijent; $\mathrm{R}^{2}=$ koeficijent determinacije; Korigirani $\mathrm{R}^{2}=$ vrijednost koeficijenta determinacije korigirana za broj varijabli u modelu; $\mathrm{F}=\mathrm{F}$-omjer; $\Delta \mathrm{R}^{2}=$ promjena vrijednosti koeficijenta determinacije; $\Delta \mathrm{F}=$ promjena vrijednosti $\mathrm{F}$-omjera; $* * p<0,001 ; * p<0,005$; Rod: 1 - mladići, 2 - djevojke.

Rezultati hijerarhijske regresijske analize za predviđanje čestine primjene strategija dobivanja na tjelesnoj težini prikazani su u Tablici 4.

Prema rezultatima hijerarhijske regresijske rod predstavlja značajan prediktor strategija dobivanja na težini te je njime objašnjeno $11 \%$ varijance kriterija. Mladići češće nego djevojke primjenjuju strategije dobivanja na težini. Uvođenjem varijable indeksa tjelesne mase $u$ drugom koraku, postotak objašnjene varijance kriterija povećao se za značajnih 6\%. Očekivano, adolescenti i adolescentice višeg indeksa tjelesne mase, rjeđe primjenjuju ove strategije. Uvođenjem nezadovoljstva tijelom u trećem koraku, postotak objašnjene varijance nije se značajno povećao, odnosno nezadovoljstvo tijelom nije se pokazalo značajnim prediktorom čestine primjene strategija dobivanja na težini. Kada se u četvrtom koraku uvela varijabla važnosti slike tijela, postotak objašnjene varijance povećala se za značajnih $2 \%$. Adolescenti i adolescentice koji slici tijela pridaju veću važnost, češće primjenjuju strategije dobivanja na težini. Uvođenjem interakcijskog efekta nezadovoljstva tijelom i važnosti slike tijela u posljednjem koraku, postotak objašnjene varijance kriterija povećao se za niskih, ali značajnih $1 \%$.

Na Slici 3 prikazane su prosječne vrijednosti čestine primjene strategija dobivanja na tjelesnoj težini kod sudionika s niskim i visokim nezadovoljstvom tijelom ovisno o važnosti koju pridaju svojoj slici tijela. Efekt važnosti slike tijela na povećanje čestine primjene strategija dobivanja na težini pokazuje drugačiji obrazac ovisno o nezadovoljstvu tijelom. Čestina primjene strategija dobivanja na težini se 


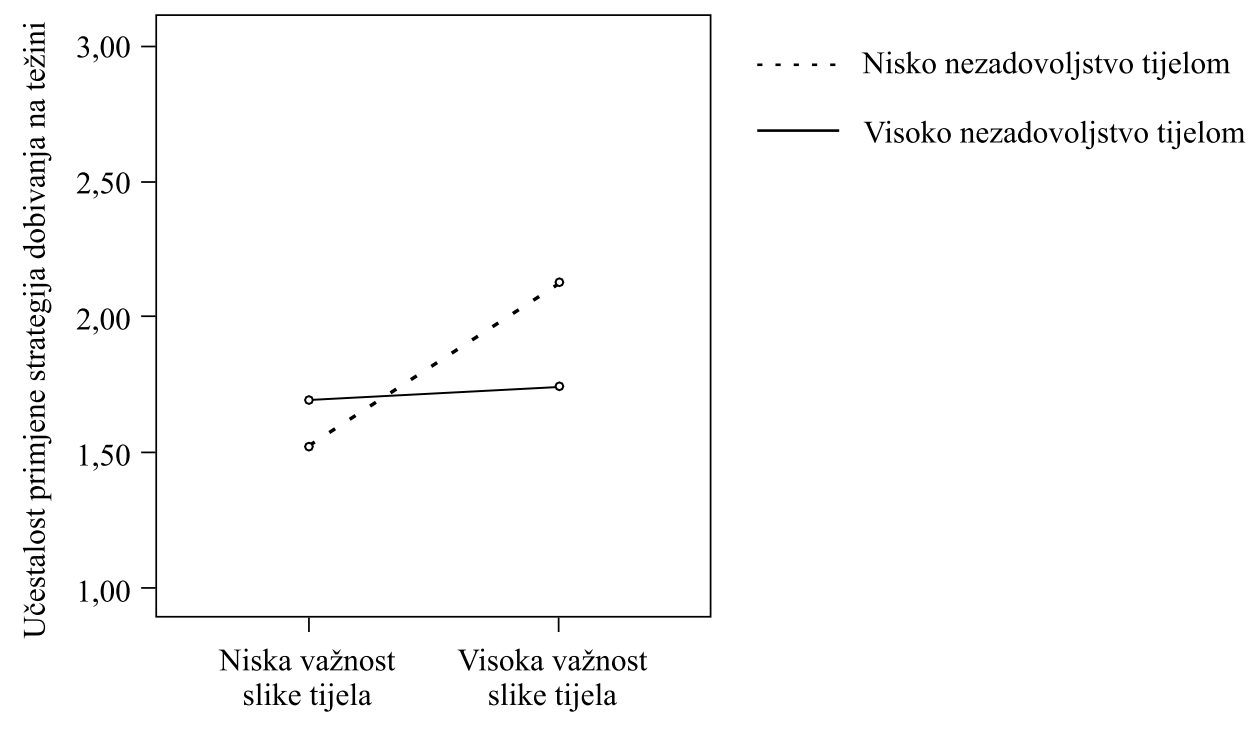

Slika 3. Interakcijski efekt važnosti slike tijela i nezadovoljstva tijelom na mjeru čestine primjene strategija dobivanja na tjelesnoj težini

kod adolescenata i adolescentica zadovoljnih tijelom znatno povećava s porastom važnosti koju pridaju slici tijela, dok kod adolescenata i adolescentica nezadovoljnih tijelom ona ostaje na istoj razini. Ovime je potvrđen moderatorski učinak važno-

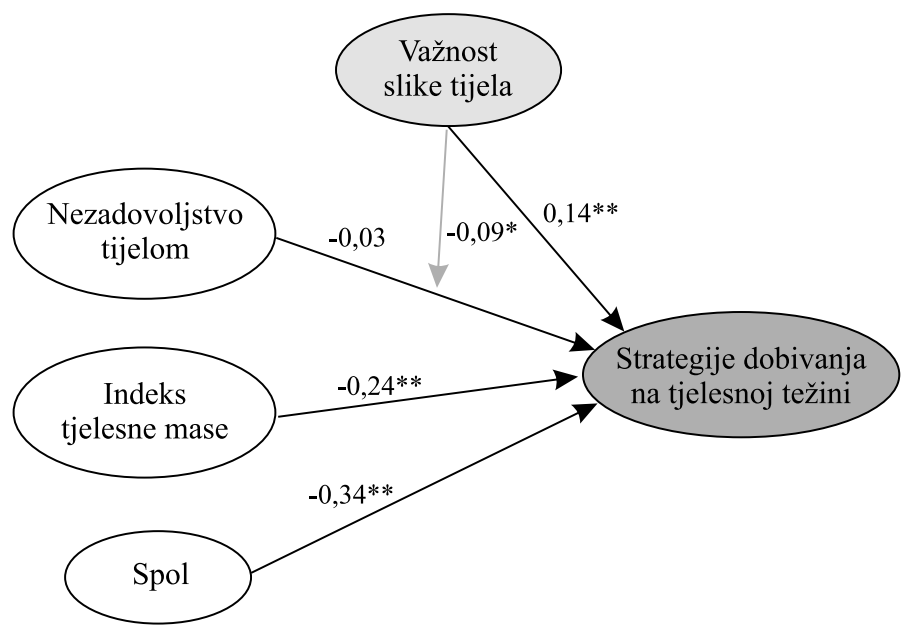

Slika 4. Dobiveni model čimbenika čestine primjene strategija dobivanja na tjelesnoj težini $(N=1056)$

Napomena: Rod: 1 - mladići; 2 - djevojke. Prikazani su standardizirani regresijski koeficijenti $(* * p<0,001 ; * p<0,05)$. 
Tablica 5. Rezultati hijerarhijske regresijske analize predviđanja čestine primjene strategija učvršćivanja mišića $(N=1056)$

\begin{tabular}{|c|c|c|c|c|c|c|}
\hline & & & & Koraci & & \\
\hline & Prediktori & 1. & 2. & 3. & 4. & 5. \\
\hline 1 & Rod & $-0,19^{* *}$ & $-0,18^{* *}$ & $-0,20 * *$ & $-0,20 * *$ & $-0,20^{* *}$ \\
\hline 2 & Indeks tjelesne mase & & 0,02 & 0,00 & 0,00 & 0,00 \\
\hline 3 & Nezadovoljstvo tijelom & & & 0,07 & 0,06 & 0,06 \\
\hline 4 & Važnost slike tijela & & & & $0,43 * *$ & $0,44^{* *}$ \\
\hline 5 & $\begin{array}{l}\text { Nezadovoljstvo tijelom } \\
\times \text { Važnost slike tijela }\end{array}$ & & & & & 0,03 \\
\hline & $\mathrm{R}^{2}$ & 0,04 & 0,04 & 0,04 & 0,23 & 0,23 \\
\hline & Korigirani $\mathrm{R}^{2}$ & 0,03 & 0,03 & 0,04 & 0,22 & 0,22 \\
\hline & $\mathrm{F}$ & $37,65 * *$ & $18,99 * *$ & $14,05^{* *}$ & $76,64 * *$ & $61,50 * *$ \\
\hline & $\Delta \mathrm{R}^{2}$ & & 0,00 & 0,00 & 0,19 & 0,00 \\
\hline & $\Delta \mathrm{F}$ & & 0,35 & 3,94 & $254,39 * *$ & 0,96 \\
\hline
\end{tabular}

Legenda: $\beta=$ standardizirani regresijski koeficijent; $\mathrm{R}^{2}=$ koeficijent determinacije; Korigirani $\mathrm{R}^{2}=$ vrijednost koeficijenta determinacije korigirana za broj varijabli u modelu; $\mathrm{F}=\mathrm{F}$-omjer; $\Delta \mathrm{R}^{2}=$ promjena vrijednosti koeficijenta determinacije; $\Delta \mathrm{F}=$ promjena vrijednosti $\mathrm{F}$-omjera; $* * p<0,001 ; * p<0,05$; Rod: 1 - mladići, 2 - djevojke.

sti slike tijela na odnos između nezadovoljstva tijelom i čestine primjene strategija dobivanja na težini.

Model čimbenika čestine primjene strategija dobivanja na tjelesnoj težini dobiven u ovom istraživanju prikazan je na Slici 4.

U Tablici 5 prikazani su rezultati hijerarhijske regresijske analize za predviđanje čestine primjene strategija učvršćivanja mišića.

Rod se prema rezultatima hijerarhijske regresijske analize pokazao značajnim prediktorom strategija učvršćivanja mišića kojim se objašnjava $3 \%$ varijance kriterija. Mladići češće nego djevojke primjenjuju strategije učvršćivanja mišića. Uvođenjem varijable indeksa tjelesne mase u drugom koraku, postotak objašnjene varijance kriterija nije se značajno povećao, kao ni uvođenjem nezadovoljstva tijelom u trećem koraku. Dakle, ni indeks tjelesne mase, kao ni nezadovoljstvo tijelom nisu se pokazali značajnim prediktorima čestine primjene strategija učvršćivanja mišića. Međutim, uvođenjem varijable važnosti slike tijela u četvrtom koraku, postotak objašnjene varijance povećao se za značajnih 19 \%. Adolescenti i adolescentice koji slici tijela pridaju veću važnost, češće primjenjuju strategije učvršćivanja mišića. Uvođenjem interakcijskog efekta nezadovoljstva tijelom i važnosti slike tijela u posljednjem koraku, postotak objašnjene varijance kriterija se nije značajno povećao. Iako je varijabla važnosti slike tijela značajan prediktor čestine primjene strategija učvršćivanja mišića, njena interakcija s nezadovoljstvom tijelom nije se pokazala 
Tablica 6. Rezultati hijerarhijske regresijske analize predviđanja čestine primjene strategija povećanja mišića $(N=1056)$

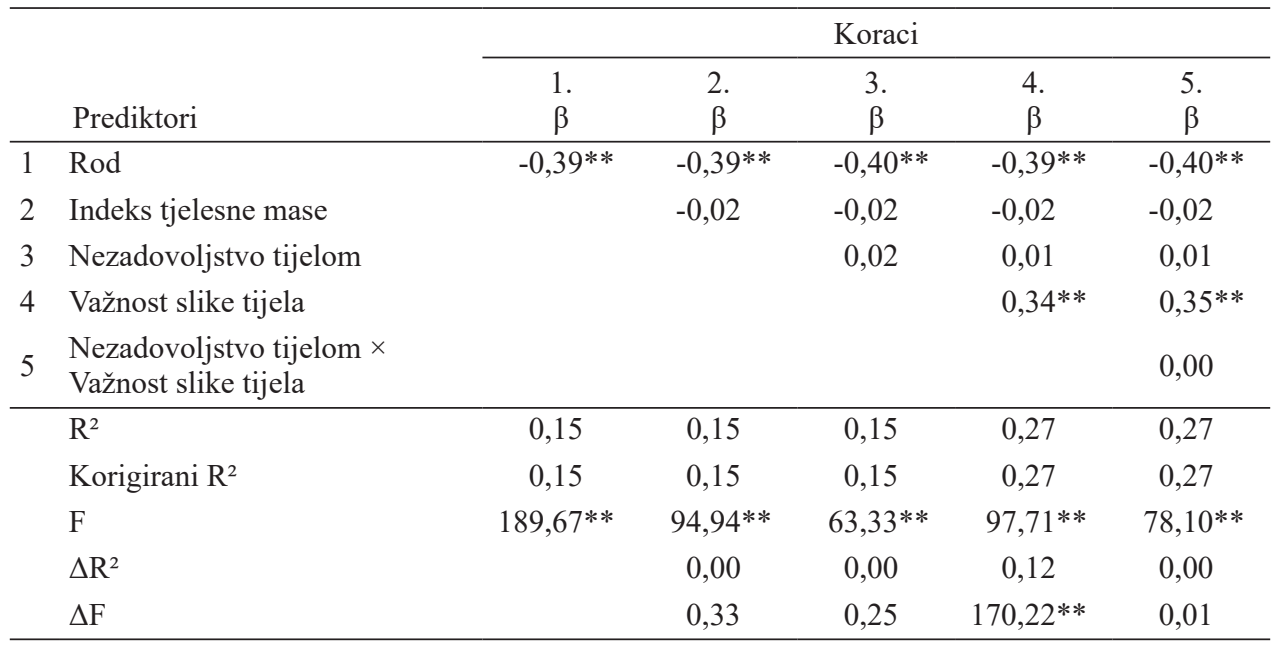

Legenda: $\beta=$ standardizirani regresijski koeficijent; $\mathrm{R}^{2}=$ koeficijent determinacije; Korigirani $\mathrm{R}^{2}=$ vrijednost koeficijenta determinacije korigirana za broj varijabli u modelu; $\mathrm{F}=\mathrm{F}$-omjer; $\Delta \mathrm{R}^{2}=$ promjena vrijednosti koeficijenta determinacije; $\Delta \mathrm{F}=$ promjena vrijednosti $\mathrm{F}$-omjera; ${ }^{* *} p<, 001 ;{ }^{*} p<, 05$; Rod: 1 - mladići, 2 - djevojke.

značajnim prediktorom ovog kriterija, odnosno varijabla važnosti slike tijela nema moderatorski utjecaj na odnos između nezadovoljstva tijelom i čestine primjene strategija učvršćivanja mišića.

Rezultati hijerarhijske regresijske analize za predviđanje čestine primjene strategija povećanja mišića prikazani su u Tablici 6 .

Rod je značajan prediktor strategija povećanja mišića kojim se objašnjava $15 \%$ varijance kriterija. Mladići očekivano češće nego djevojke primjenjuju strategije povećanja mišića. Uvođenjem varijable indeksa tjelesne mase u drugom koraku, postotak objašnjene varijance se nije značajno povećao, kao ni uvođenjem nezadovoljstva tijelom u trećem koraku, čime se indeks tjelesne mase i nezadovoljstvo tijelom nisu pokazali značajnim prediktorima čestine primjene strategija povećanja mišića. Međutim, uvođenjem varijable važnosti slike tijela u četvrtom koraku, postotak objašnjene varijance povećao se za značajnih $12 \%$. Adolescenti i adolescentice koji slici tijela pridaju veću važnost, češće primjenjuju strategije povećanja mišića. Uvođenjem interakcijskog efekta nezadovoljstva tijelom i važnosti slike tijela u posljednjem koraku, postotak objašnjene varijance kriterija se nije značajno povećao. Iako je varijabla važnosti slike tijela značajan prediktor čestine primjene strategija povećanja mišića, njena interakcija s nezadovoljstvom tijelom nije se pokazala značajnim prediktorom ovog kriterija, odnosno varijabla važnosti slike 


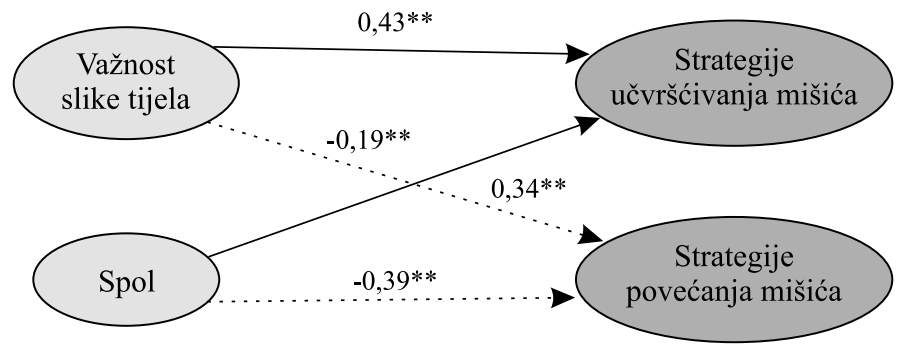

Slika 5. Dobiveni modeli čimbenika čestine primjene strategija učvršćivanja i strategija povećanja mišića $(N=1056)$

Napomena. Rod: 1 - mladići; 2 - djevojke. Prikazani su standardizirani regresijski koeficijenti $(* * p<0,001)$.

tijela nema moderatorski utjecaj na odnos između nezadovoljstva tijelom i čestine primjene strategija povećanja mišića.

Modeli čimbenika čestine primjene strategija učvršćivanja i strategija povećanja mišića dobiveni u ovom istraživanju prikazani su na Slici 5.

\section{RASPRAVA}

Ovim smo istraživanjem željeli ispitati doprinos roda, indeksa tjelesne mase, nezadovoljstva tijelom i važnosti slike tijela u objašnjavanju čestine primjene nekoliko najčešćih strategija za promjenu tjelesnog izgleda kod adolescentica i adolescenata te moderatorski utjecaj važnosti slike tijela na odnos između nezadovoljstva tijelom i čestine primjene strategija za promjenu tjelesnog izgleda.

Rezultati provedenog istraživanja pokazuju kako adolescentice očekivano češće nego adolescenti primjenjuju strategije mršavljenja. Dobivene nalaze podupiru rezultati ranijih istraživanja prema kojima u mnogim razvijenim zemljama Zapada 50 do 80 \% adolescentnih djevojaka želi biti mršavije, a više od 50 \% njih izvještava o provođenju dijete (Levine i Smolak, 2002). Istraživanjem na uzorku hrvatskih srednjoškolaca dobivaju se slični rezultati, prema kojima oko 50\% djevojaka smatra kako bi njihova idealna težina trebala biti za prosječno 3 do 4 kilograma niža od trenutačne (Gladović, 1999; Livazović i Mudrinić, 2017). Istraživanje provedeno na uzorcima hrvatskih adolescenata također nalaze kako dijetu provodi čak oko $40 \%$ djevojaka, a njih oko $8 \%$ pokazuje odstupanja u navikama hranjenja, dok među mladićima dijetu provodi njih 14\%, a 5,5\% pokazuje odstupajuće navike hranjenja (Pokrajac-Bulian i sur., 2007). Munjas Samarin (2011), kao i Livazović i Mudrinić (2017) u svojim istraživanjima na hrvatskim srednjoškolcima također pronalaze kako djevojke u značajno većoj mjeri iskazuju odstupajuća ponašanja 
hranjenja u odnosu na mladiće, zbog čega se čini kako je dijeta, kao način kontrole tjelesne težine, u tolikoj mjeri rašireno i učestalo ponašanje među djevojkama da se smatra normativnim (McHale i sur., 2001; Smink i sur., 2012). Mladići, s druge strane, izražavaju želju za izgradnjom svoga tijela i povećanjem mišićavosti te su, prema nalazima mnogih istraživanja, više nego djevojke, skloni primjeni strategija dobivanja na tjelesnoj težini i strategija povećanja mišićavosti (Drenowski, Kurth i Krahn, 1995; Gladović, 1999; McCabe i Ricciardelli, 2001; McCabe i Ricciardelli, 2004; Pokrajac-Bulian i sur., 2007).

Indeks tjelesne mase pokazao se značajnim prediktorom primjene strategija $\mathrm{mr}-$ šavljenja, pri čemu je utvrđeno kako adolescenti i adolescentice višeg indeksa tjelesne mase češće primjenjuju ove strategije. Ovaj je nalaz sukladan očekivanjima. Naime, iako su djevojke općenito sklonije strategijama mršavljenja u odnosu na mladiće, istraživanja pokazuju kako su i prekomjerno teški mladići skloni njihovoj primjeni (Furnham i Calnan, 1998; McCabe i Ricciardelli, 2001; McCabe i Ricciardelli, 2004; McCreary i Sasse, 2000; O’Dea i Abraham, 1999).

Nadalje, varijable nezadovoljstva tijelom i važnosti slike tijela zasebno, kao i njihova interakcija, također su se pokazale značajnim prediktorima primjene strategija mršavljenja. Adolescenti i adolescentice koji su nezadovoljniji tijelom, češće primjenjuju strategije mršavljenja od onih zadovoljnijih tijelom, kao i oni koji slici tijela pridaju veću važnost. Međutim, čestina primjene strategija mršavljenja kod adolescenata i adolescentica nezadovoljnih tijelom znatno raste s povećanjem važnosti koju pridaju slici tijela, dok se kod adolescenata i adolescentica zadovoljnijih tijelom ona tek blago povećava, što upućuje na očekivani moderatorski učinak važnosti slike tijela na odnos između nezadovoljstva tijelom i čestine primjene strategija mršavljenja. Ovi nalazi u skladu su s rezultatima istraživanja prema kojima su važnost slike tijela, kao i nezadovoljstvo tijelom, značajni čimbenici u razumijevanju odstupajućih navika hranjenja i poremećaja hranjenja (Rieder i Ruderman, 2001). McCabe i Ricciardelli (2003b; 2006) također navode kako se, uz nezadovoljstvo tijelom, i važnost slike tijela pokazala kao snažan prediktor ekstremnih ponašanja koja za cilj imaju promjenu tjelesnog izgleda kod adolescenata oba roda. Iste autorice nalaze kako su adolescentice, koje veliku važnost pridaju svom tjelesnom izgledu, ali su i nezadovoljne tijelom, rizične za primjenu ekstremnih strategija za promjenu tjelesnog izgleda (McCabe i Ricciardelli, 2006).

Kao značajan prediktor strategija dobivanja na težini u ovom se istraživanju, $u$ skladu s dosadašnjim istraživanjima, pokazao rod adolescenata, pri čemu je utvrđeno kako ih mladići primjenjuju češće nego djevojke. Kao što je spomenuto, ovaj je nalaz sukladan rezultatima mnogih istraživanja prema kojima su mladići, više nego djevojke, skloni primjeni strategija dobivanja na tjelesnoj težini (Furnham i Calnan, 1998; Gladović, 1999; McCabe i Ricciardelli, 2001; McCabe i Ricciardelli, 2004), a što se može objasniti razlikama u nametnutim idealima tjelesnog izgleda - mršavost ženskog tijela u odnosu na izgrađeno krupno mišićavo muško tijelo. 
Indeks tjelesne mase također je značajan prediktor primjene strategija dobivanja na težini. Očekivano, adolescenti i adolescentice višeg indeksa tjelesne mase, rjeđe primjenjuju strategije dobivanja na težini. Ovaj je nalaz u skladu s opisanim rezultatom ovog istraživanja prema kojem adolescenti i adolescentice višeg indeksa tjelesne mase češće primjenjuju strategije mršavljenja. Suprotno očekivanjima, nezadovoljstvo tijelom nije značajan prediktor primjene strategija dobivanja na težini, za razliku od važnosti slike tijela koja se pokazala značajnim prediktorom njihove primjene. Adolescenti i adolescentice koji slici tijela pridaju veću važnost, češće primjenjuju strategije dobivanja na težini. Značajnim se pokazao i moderatorski učinak važnosti slike tijela na odnos između nezadovoljstva tijelom i čestine primjene strategija dobivanja na težini, pri čemu on pokazuje drugačiji obrazac ovisno o razini nezadovoljstva tijelom. Čestina primjene strategija dobivanja na težini se kod adolescenata i adolescentica zadovoljnih tijelom znatno povećava s porastom važnosti koju pridaju slici tijela, dok kod adolescenata i adolescentica nezadovoljnih tijelom ostaje na istoj razini. Objašnjenje opisanih dobivenih nalaza moguće je potražiti u rezultatima nekih dosadašnjih, ali malobrojnijih istraživanja koja su, osim nezadovoljstva tijelom, uključivala varijablu važnosti slike tijela. Tako, primjerice, McCabe i Ricciardelli (2006) navode da važnost koju adolescenti pridaju svom tjelesnom izgledu ima snažniji učinak na sklonost primjeni strategija za promjenu tjelesnog izgleda nego samo nezadovoljstvo njime, što je u skladu s nalazima ovog istraživanja. Vjerojatnije je kako osoba nezadovoljna tijelom koja, međutim, vlastiti tjelesni izgled ne smatra važnim, neće primjenjivati strategije za njegovu promjenu (Cash, 2012; Crow i sur., 2006; Loth i sur., 2014; McCabe i Ricciardelli, 2003a).

U ispitivanju predikcije čestine primjene strategija učvršćivanja mišića te strategija povećanja mišića, rezultati ovog istraživanja pokazuju kako je, u skladu s očekivanjima, rod značajan prediktor njihove primjene, pri čemu je utvrđeno kako mladići češće nego djevojke primjenjuju strategije učvršćivanja i povećanja mišića. O’Dea i Abraham (1999) nalaze kako mladići izražavaju želju za izgradnjom svoga tijela i povećanjem mišićavosti te su, prema nalazima mnogih istraživanja, više nego djevojke, skloni primjeni strategija povećanja mišićavosti, kao što su skloniji i primjeni, prethodno opisanih, strategija dobivanja na tjelesnoj težini (Drenowski i sur., 1995; Furnham i Calnan, 1998; McCabe i Ricciardelli, 2001; McCabe i Ricciardelli, 2004). Vrlo je vjerojatno kako mladići, u želji za dostizanjem nametnutog ideala muške ljepote, nastoje povećati mišićavost svoga tijela (Griffiths i sur., 2016).

Suprotno očekivanjima, indeks tjelesne mase i nezadovoljstvo tijelom nisu značajni prediktori primjene strategija učvršćivanja i strategije povećanja mišića za razliku od važnosti slike tijela. Očekivano, adolescenti i adolescentice koji slici tijela pridaju veću važnost, češće primjenjuju strategije učvršćivanja i strategije povećanja mišića. Iako je važnost slike tijela značajan prediktor čestine primjene ovih strategija, njena interakcija s nezadovoljstvom tijelom nije se pokazala značajnom, čime nije potvrđen pretpostavljeni moderatorski učinak važnosti slike tijela na od- 
nos između nezadovoljstva tijelom i čestine primjene strategija učvršćivanja mišića te između nezadovoljstva tijelom i čestine primjene strategija povećanja mišića.

Objašnjenje nalaza kako indeks tjelesne mase nije značajan prediktor primjene strategija učvršćivanja i povećanja mišića možemo potražiti u nalazima istraživanja prema kojima su i prekomjerni teški mladići, kao i oni ispodprosječne tjelesne težine skloni primjeni strategija povećanja mišićavosti (Furnham i Calnan, 1998; McCabe i Ricciardelli, 2001; McCabe i Ricciardelli, 2004; McCreary i Sasse, 2000; O’Dea i Abraham, 1999). Također je moguće da i djevojke, neovisno o svom indeksu tjelesne mase, primjenjuju strategije kojima će učvrstiti svoje mišiće kako bi se približile idealu ne samo mršavog već i čvrstog ženskog tijela (Levine i Smolak, 2002). Iako se nezadovoljstvo tijelom u našem istraživanju nije pokazalo značajnim prediktorom primjene strategija učvršćivanja i povećanja mišića, važnost slike tijela jest te, uz rod, predstavlja jedini značajan prediktor čestine primjene ovih strategija. U skladu s tim su ranije spomenuti rezultati istraživanja prema kojima važnost koju adolescenti pridaju svom tjelesnom izgledu, ima snažniji učinak na sklonost primjeni strategija za promjenu tjelesnog izgleda nego samo nezadovoljstvo njime (McCabe i Ricciardelli, 2006), kao i nalaz da je važnost slike tijela snažan prediktor povećanja mišićavosti kod adolescenata oba roda (McCabe i Ricciardelli, 2003b).

Zaključno, važnost slike tijela se u odnosu na nezadovoljstvo tijelom i indeks tjelesne mase, pokazala značajnim prediktorom primjene svih ispitanih strategija za promjenu tjelesnog izgleda (strategije mršavljenja, stretegije dobivanja na težini, strategije učvršćivanja mišića, strategije povećanja mišića), što je u skladu s dosadašnjim, ali malobrojnijim istraživanjima čiji nalazi upućuju na važnost slike tijela kao značajnog čimbenika u razumijevanju odstupajućih navika hranjenja i poremećaja hranjenja (Cash, 2012; Loth i sur., 2014; Ricciardelli i McCabe, 2001; Rieder i Ruderman, 2001) te kako važnost slike tijela predstavlja snažan prediktor ekstremnih ponašanja koja za cilj imaju promjenu tjelesnog izgleda kod adolescenata oba roda (McCabe i Ricciardelli, 2006). Nezadovoljstva tijelom i važnosti slike tijela zasebno, kao i njihova interakcija, pokazali su se značajnim prediktorima primjene strategija mršavljenja. Varijabla važnost slike tijela ima moderatorski učinak na odnos između nezadovoljstva tijelom i čestine primjene strategija mršavljenja, kao i na čestinu primjene strategija dobivanja na težini. Iako je varijabla važnosti slike tijela značajan prediktor čestine primjene strategija povećanja mišića, njena interakcija s nezadovoljstvom tijelom nije se pokazala značajnim prediktorom ovog kriterija, odnosno varijabla važnosti slike tijela nema moderatorski utjecaj na odnos između nezadovoljstva tijelom i čestine primjene strategija povećanja mišića. U dosadašnjim su istraživanjima ovakvi odnosi rjeđe ispitivani.

Znanstvene spoznaje dobivene ovim istraživanjem daju važan uvid u manje istraženo područje nezadovoljstva tijelom i strategija za promjenu tjelesnog izgleda kod osoba muškoga roda, kao i na ulogu važnosti slike tijela u primjeni strategija za promjenu tjelesnog izgleda koja je u dosadašnjim istraživanjima često bila zanemarena. 
Praktične implikacije, ograničenja istraživanja i

preporuke za buduća istraživanja

U pogledu praktičnog doprinosa dobivene spoznaje ovog istraživanja upućuju na važnost osvještavanja nezadovoljstva tijelom te posebice važnosti koja osoba pridaje svom tjelesnom izgledu kako bi se preventivno moglo djelovati na primjenu štetnih strategija za promjenu tjelesnog izgleda, a s ciljem pružanja pomoći te sprječavanja i/ili ublažavanja mnogih problema i teškoća koji mogu nastati zbog izražene preokupacije tjelesnim izgledom i nezadovoljstva tijelom. Važnim se čini poučiti mlade ljude o štetnosti ekstremnih strategija za promjenu tjelesnog izgleda te o njihovim dugoročnim posljedicama za organizam.

Unatoč određenim prednostima, ovo istraživanje sadrži nedostatke i ograničenja na koje je potrebno upozoriti. Prije svega, s obzirom na to da je istraživanje korelacijsko, ne omogućuje nam donošenje zaključaka o uzročno-posljedičnim vezama među varijablama. Nedostatak istraživanja sadržan je i u metodi prikupljanja podataka o tjelesnoj visini i težini sudionika temeljenoj na samoiskazima. Iako Ambrosi-Randić i Pokrajac-Bulian (2007) navode kako su korelacije između izmjerenih vrijednosti težine $\mathrm{i}$ visine te vrijednosti dobivenih samoiskazima veće od 0,93 , ne možemo biti sigurni da su sudionici davali točne podatke o svojoj visini i težini.

Radi dobivanja bogatijeg uvida u specifičnosti nezadovoljstva tijelom u adolescenciji i uvid u načine suočavanja s pubertalnim promjenama na tjelesnom planu i negativnim utjecajima na sliku tijela, bila bi poželjna primjena kvalitativne metodologije, primjerice provedba fokusnih grupa ili polustrukturiranih intervjua s manjim brojem sudionika. Također, $\mathrm{u}$ budućim bi istraživanjima bilo poželjno primijeniti istraživačke nacrte s longitudinalnom komponentom, koji bi omogućili uvid u razvoj i promjene u nezadovoljstvu tijelom, važnosti slike tijela i primjeni strategija za promjenu tjelesnog izgleda.

\section{LITERATURA}

Ambrosi-Randić, N. i Pokrajac-Bulian, A. (2007).Self-reported versus measured weight and height by adolescent girls: A Croatian sample. Perceptual and Motor Skills, 104, 79-82. https://doi.org/10.2466/pms.104.1.79-82

Ambrosi-Randić, N. (2004). Razvoj poremećaja hranjenja. Jastrebarsko: Naklada Slap.

Angell, M. P., Chester, N., Green, D., Somauroo, J., Whyte, G. i George, K. (2012).Anabolic steroids and cardiovascular risk. Sports Medicine, 42, 119-134. https://doi. org/10.2165/11598060-000000000-00000

Blashill, A. J. i Wilhelm, S. (2014). Body image distortions, weight, and depression in adolescent boys: Longitudinal trajectories into adulthood. Psychology of Men \& Masculinity, 15(4), 445-451. http://dx.doi.org/10.1037/a0034618

Bralić, I. i Kovačić, V. (2005). Social and behavioural determinants of body mass index among adolescent females in Croatia. Public Health, 119, 189-191. 
Cafri, G., Thompson, J.K., Ricciardelli, L., McCabe, M., Smolak, L. i Yesalis, C. (2005). Pursuit of the muscular ideal: Physical and psychological consequences and putative risk factors. Clinical Psychology Review, 25, 215-239. https://doi.org/10.1016/j. cpr.2004.09.003

Cash, T. F., Melnyk, S. E. i Hrabosky, J. I. (2004). The assessment of body image investment: An extensive revision of the Appearance Schemas Inventory. International Journal of Eating Disorders, 35(3), 305-316. https://doi.org/10.1002/eat.10264

Cash, T. F., Phillips, K. A., Santos, M. T. \& Hrabosky, J. I. (2004). Measuring "negative body image": Validation of the Body Image Disturbance Questionnaire in a nonclinical population. Body Image, 1(4), 363-372. https://doi.org/10.1016/j.bodyim.2004.10.001

Cash, T. F. (2002).Cognitive-behavioral perspectives on body image. U: Cash, T. F., Pruzinsky, T. (Ur.), Body image: A Handbook of Theory, Research, and Clinical Practice, $38-46$.

Cash, T. F. (2012).Cognitive-behavioral perspectives on body image. U T. F. Cash (Ur.), Encyclopedia of Body Image and Human Appearance, 334-342. Academic Press. https://doi.org/10.1016/C2010-1-66177-9

Cattarin, J. i Thompson, J. K. (1994).A three year longitudinal study of body image and eating disturbance in adolescent females. Eating Disorders: The Journal of Prevention and Treatment, 2, 114-125. https://doi.org/10.1080/10640269408249107

Crow, S., Eisenberg, M. E., Story, M. i Neumark-Sztainer, D. (2006). Psychosocial and behavioral correlates of dieting among overweight and non-overweight adolescents. Journal of Adolescent Health, 38, 569-574. https://doi.org/10.1016/j.jadohealth.2005.05.019

Davison, T.E. i McCabe, M.P. (2006). Adolescent body image and psychosocial functioning. The Journal of Social Psychology, 146, 15-30. https://doi.org/10.3200/SOCP.146.1.1530

Drenowski, A., Kurth, C.L. i Krahn, D.D. (1995). Effects of body image on dieting, exercise, and anabolic steroid use in adolescent males. International Journal of Eating Disorders, 17(4), 381-386. https://doi.org/10.1002/1098-108X(199505)17:4<381::AIDEAT2260170410>3.0.CO;2-V

Erceg Jugović, I. (2015). Čimbenici nezadovoljstva tijelom u adolescenciji (Neobjavljena doktorska disertacija). Filozofski fakultet, Sveučilište u Zagrebu, Zagreb.

Ferreiro, F., Seoane, G. i Senra, C. (2014). Towards understanding the role of body dissatisfaction in the gender differences in depressive symptoms and disordered eating: A longitudinal study during adolescence. Journal of Adolescence, 37, 73-84. https://doi. org/10.1016/j.adolescence.2013.10.013

Furnham, A. i Calnan, A. (1998). Eating disturbance, self-esteem, reasons for exercising and body weight dissatisfaction in adolescent males. European Eating Disorders Review, 6, 58-72. https://doi.org/10.1002/(SICI)1099-0968(199803)6:1<58::AIDERV184>3.0.CO;2-V

Gardner, R.M., Friedman, B.N., Stark, K. i Jackson, N.A. (1999). Body size estimation in children six through fourteen: A longitudinal study. Perceptual and Motor Skills, 88, 541-555. https://doi.org/10.2466/pms.1999.88.2.541

Gladović, B. (1999). Nezadovoljstvo vlastitim tjelesnim izgledom kod studenata $i$ studentica(Neobjavljeni diplomski rad). Filozofski fakultet, Sveučilište u Rijeci, Rijeka. 
Gondoli, D. M., Corning, A.F., Salafia, E.H.B., Bucchianeri, M.M. i Fitzsimmons, E.E. (2011). Heterosocial involvement, peer pressure for thinness, and body dissatisfaction among young adolescent girls. Body Image, 8(2), 143-148. https://doi.org/10.1016/j. bodyim.2010.12.005

Griffiths, S., Hay, P., Mitchison, D., Mond, J. M., McLean, S. A., Rodgers, B., Massey, R. i Paxton, S. J. (2016). Sex differences in the relationships between body dissatisfaction, quality of life and psychological distress. Australian and New Zealand Journal of Public Health, 40, 518-522. https://doi.org/10.1111/1753-6405.12538

Grogan, S. (2017).Body image: Understanding body dissatisfaction in men, women and children. London; New York: Routledge, Taylor \& Francis Group. https://doi. org/10.4324/9781315681528

Gutin, B. (2011). Diet vs. exercise for the prevention of pediatric obesity: The role of exercise. International Journal of Obesity, 35, 29-32. https://doi.org/10.1038/ijo.2010.140

Harris, M. A., Dunn, M. J. i Alwyn, T. (2016).A qualitative exploration of the motivations underlying anabolic-androgenic steroid use from adolescence into adulthood. Health Psychology Report, 4(4), 315-320. http://dx.doi.org/10.5114/hpr.2016.61669

Jakatdar, T. A., Cash, T. F. i Engle, E. K. (2006). Body-image thought processes: The development and initial validation of the Assessment of Body-Image Cognitive Distortions. Body Image, 3(4), 325-333. https://doi.org/10.1016/j.bodyim.2006.09.001

Jampel, J. D., Murray, S. B., Griffiths, S. \& Blashill, A. J. (2016). Self-perceived weight and anabolic steroid misuse among us adolescent boys. Journal of Adolescent Health, 58(4), 397-402. https://doi.org/10.1016/j.jadohealth.2015.10.003

Karazsia, B. T., Murnen, S. K. i Tylka, T. L. (2017). Is body dissatisfaction changing across time? A cross-temporal meta-analysis. Psychological Bulletin, 143(3), 293. http:// dx.doi.org/10.1037/bul0000081

Kukić, M. (2013). Pretilost adolescenata - rizični i zaštitni čimbenici (Neobjavljena doktorska disertacija). Filozofski fakultet, Sveučilište u Zagrebu, Zagreb.

Levine, M. P. i Smolak, L. (2002).Body image: Development in adolescence. U T.F. Cash, T. Pruzinsky (Ur.), Body Image: A Handbook of Theory, Research, and Clinical Practice, 74-82. New York: The Guilford Press. https://doi.org/10.1080/10640260390218738

Livazović, G. i Mudrinić, I. (2017). Nezadovoljstvo tjelesnim izgledom i ponašanja povezana s poremećajima u prehrani adolescenata. Kriminologija i socijalna integracija: časopis za kriminologiju, penologiju i poremećaje u ponašanju, 25(1), 71-89. https:// doi.org/10.31299/ksi.25.1.3

Loth, K. A., MacLehose, R., Bucchianeri, M., Crow, S. i Neumark-Sztainer, D. (2014). Predictors of dieting and disordered eating behaviors from adolescence to young adulthood. Journal of Adolescent Health, 55(5), 705-712. https://doi.org/10.1016/j.jadohealth.2014.04.016

Lunner, K., Wertheim, E. H., Thompson, J. K., Paxton, S. J., McDonald, F. i Halvaarson, K. S. (2000). A cross-cultural examination of weight-related teasing, body image, and eating disturbance in Swedish and Australian samples. International Journal of Eating Disorders, 28, 430-435. https://doi.org/10.1002/1098-108X(200012)28:4<430::AIDEAT11>3.0.CO;2-Y 
McCabe, M. P. i Ricciardelli, L.A. (2001). Parent, peer, and media influences on body image and strategies to both increase and decrease body size among adolescent boys and girls. Adolescence, 36, 225-240.

McCabe, M. P. i Ricciardelli, L.A. (2003a). Body image and strategies to lose weight and increase muscle among boys and girls. Health Psychology, 22, 39-46.

McCabe, M. P. i Ricciardelli, L.A. (2003b). Sociocultural Influences on Body Image and Body Change Among Adolescent Boys and Girls. The Journal of Social Psychology, 143(1), 5-26. https://doi.org/10.1080/00224540309598428

McCabe, M.P. i Ricciardelli, L. A. (2004). A longitudinal study of pubertal timing and extreme body change behaviors among adolescent boys and girls. Adolescence, 39, 145-166.

McCabe, M. P. i Ricciardelli, L.A. (2006). A Prospective Study of Extreme Weight Change Behaviors Among Adolescent Boys and Girls. Journal of Youth and Adolescence, 35(3), 425-434. https://doi.org/10.1007/s10964-006-9062-5

McCreary, D. R. i Sasse, D.K. (2000). An exploration of the drive for muscularity in adolescent boys and girls. Journal of American College Health, 48, 297-304. https://doi. org/10.1080/07448480009596271

McHale, S.M., Corneal, D.A., Crouter, A.C. i Birch, L.L. (2001). Gender and weight concerns in early and middle adolescence: Links with well-being and family characteristics. Journal of Clinical Child Psychology, 30, 338-348. https://doi.org/10.1207/ S15374424JCCP3003_6

Melnyk, S. E., Cash, T. F., i Janda, L. H. (2004). Body image ups and downs: Prediction of intra-individual level and variability of women's daily body image experiences. Body Image, 1(3), 225-235. https://doi.org/10.1016/j.bodyim.2004.03.003

Munjas Samarin, R. (2011). Provjera višedimenzionalnoga modela razvoja poremećaja hranjenja (Neobjavljena doktorska disertacija). Filozofski fakultet, Sveučilište u Zagrebu, Zagreb.

Muris, P., Meesters, C., van de Blom, W. i Mayer, B. (2005).Biological, psychological, and sociocultural correlates of body change strategies and eating problems in adolescent boys and girls. Eating Behaviors, 6(1),11-22. https://doi.org/10.1016/j.eatbeh.2004.03.002

Neumark-Sztainer, D., Story, M., Hannan, P.J., Perry, C.L. i Irving, L.M. (2002). Weightrelated concerns and behaviors among overweight and nonoverweight adolescents: Implications for preventing weight-related disorders. Archives of Pediatric and Adolescent Medicine, 156, 171-178. https://doi.org/10.1001/archpedi.156.2.171

O’Connor, B. P. (2014). A Reason Why Body Image Importance Judgments May Appear Un-Important to Self-Esteem and Eating Disorders. International Journal of Psychology Research, 9(3), 237.

O'Dea, J. A. i Abraham S. (1999). Onset of disordered eating attitudes and behaviors in early adolescence: interplay of pubertal status, gender, weight, and age. Adolescence, 34(136), 671-679.

Pokrajac-Bulian, A., Mohorić, T. i Đurović, D. (2007). Odstupajuće navike hranjenja, nezadovoljstvo tijelom i učestalost provođenja dijete kod hrvatskih srednjoškolaca. Psihologijske teme, 16, 27-46.

Pokrajac-Bulian, A., Stubbs, L. i Ambrosi-Randić (2004). Različiti aspekti slike tijela i navike hranjenja u adolescenciji. Psihologijske teme, 13(1), 91-104. 
Pope, H.G., Wood, R.I., Rogol, A., Nyberg, F., Bowers, L. i Bhasin, S. (2013). Adverse health consequences of performance-enhancing drugs: An Endocrine Society scientific statement. Endocrine Reviews, 35, 341-375. https://doi.org/10.1210/er.2013-1058

Presnell, K., Bearman, S. K. i Stice, E. (2004). Risk factors for body dissatisfaction in adolescent boys and girls: A prospective study. International Journal of Eating Disorders, 36, 389-401. https://doi.org/10.1002/eat.20045

Rawana, J. S. (2013). The relative importance of body change strategies, weight perception, perceived social support, and self-esteem on adolescent depressive symptoms: Longitudinal findings from a national sample. Journal of Psychosomatic Research, 75(1), 49-54. https://doi.org/10.1016/j.jpsychores.2013.04.012

Ricciardelli, L. A. i McCabe, M.P. (2001). Self-esteem and negative affect as moderators of sociocultural influences on body dissatisfaction, strategies to decrease weight, and strategies to increase muscles among adolescent girls and boys. Sex Roles, 44, 189-207. https://doi.org/10.1023/A:1010955120359

Ricciardelli, L. A. i McCabe, M. P. (2002). Psychometric evaluation of the Body Change Inventory: An assessment instrument for adolescent boys and girls. Eating Behaviors, 2, 1-15. https://doi.org/10.1016/S1471-0153(01)00044-7

Rieder, S. i Ruderman, A. (2001). Cognitive factors associated with binge and purge eating behaviors: The interaction of body dissatisfaction and body image importance. Cognitive Therapy and Research, 25, 801-812. https://doi.org/10.1023/A:1012979625364

Rosen, J.C. (1990). Body image disturbances in eating disorders. U T.F. Cash, T. Pruzinsky (Ur.), Body images development deviance and change, 190-214. New York: Guilford Press.

Rudiger, J. A., Cash, T. F., Roehrig, M. i Thompson, J. K. (2007). Day-to-day body-image states: Prospective predictors of intra-individual level and variability. Body Image, 4(1), 1-9. https://doi.org/10.1016/j.bodyim.2006.11.004

Smink, F. R. E., van Hoeken, D. i Hoek, H. W. (2012). Epidemiology of eating disorders: incidence, prevalence and mortality rates. Current Psychiatry Reports, 14(4), 406-414. https://doi.org/10.1007/s11920-012-0282-y

Stice, E. i Bearman, S.K. (2001). Body-image and eating disturbances prospectively predict increases in depressive symptoms in adolescent girls: A growth curve analyses. Developmental Psychology, 37, 597-607. http://dx.doi.org/10.1037/0012-1649.37.5.597

Stice, E. i Whitenton, K. (2002). Risk factors for body dissatisfaction in adolescent girls: A longitudinal investigation. Developmental Psychology, 38, 669-678.

Stice, E. (2002). Body image and bulimia nervosa. U T.F. Cash, T. Pruzinsky (Ur.), Body Image: A Handbook of Theory, Research, and Clinical Practice, 304-311. New York: The Guilford Press.

Thompson, J. K. (1992). Body image: Extent of disturbance, associated features, theoretical models, assessment methodologies, intervention strategies, and a proposal for a DSM-IV diagnostic category - Body Image Disorder. U: M. Hersen, R. M. Eisler, P. M. Miller (Ur.), Progress in Behaviour Modification, 3-54. Sycamore, IL: Sycamore Publishing Inc.

Tiggemann, M. (2011).Sociocultural perspectives on human appearance and body image: U T. F. Cash, L. Smolak (Ur.), Body Image: A Handbook of Science, Practice, and Prevention, 12-19. New York: The Guilford Press. 
Voelker, D. K., Reel, J. J. i Greenleaf, C. (2015). Weight status and body image perceptions in adolescents: current perspectives. Adolescent Health, Medicine and Therapeutics, 6 , 149. https://doi.org/10.2147/AHMT.S68344

Wertheim, E. H., Koerner, J. i Paxton, S.J. (2001).Longitudinal predictors of restrictive eating and bulimic tendencies in three different age groups of adolescent girls. Journal of Youth and Adolescence, 30, 69-81. https://doi.org/10.1023/A:1005224921891

\title{
PREDICTORS OF BODY CHANGE STRATEGIES IN ADOLESCENCE
}

\begin{abstract}
Body change strategies refer to various ways of changing and influencing the body shape, size and/or body weight as well as its muscularity. One of the factors that predict body change strategies is body dissatisfaction as a subjective negative assessment of one's physical appearance. However, the role of body image importance is less explored. Therefore, the aim of this study was to investigate the contribution of gender, body mass index, body dissatisfaction and body image importance in predicting use of different body change strategies. 1056 primary and secondary school students of average age $M=15.14$ years completed the translated and modified version of the Body Image and Body Change Inventory. Results show that gender, body mass index, body dissatisfaction and body image importance are significant predictors of practicing some of the body change strategies. Both adolescent girls and boys with a higher body mass index use weight loss strategies more frequently, while boys, compared to girls, use strategies to increase their body weight, muscle strength and size more often. The finding of this study that body image importance is a significant predictor of all of the investigated body change strategies emphasizes the role of body image importance in practicing body change strategies.
\end{abstract}

Key words: body dissatisfaction, body image importance, body change strategies, body mass index, adolescence

Primljeno: 12. 07. 2019. 
